\title{
Altered ex vivo cytokine production in zinc-deficient, pair-fed and marginally zinc-deficient growing rats is independent of serum corticosterone concentrations
}

\author{
Heather J. Hosea Blewett ${ }^{1,2}$, Edward S. Rector ${ }^{3}$ and Carla G. Taylor ${ }^{2 *}$ \\ ${ }^{1}$ Department of Agricultural, Food and Nutritional Sciences, University of Alberta, Edmonton, AB, T6G 2P5, Canada \\ ${ }^{2}$ Department of Human Nutritional Sciences, University of Manitoba, Winnipeg, MB, R3T 2N2, Canada \\ ${ }^{3}$ Department of Immunology, University of Manitoba, Winnipeg, MB, R3T 2N2, Canada
}

(Received 22 May 2007 - Revised 3 January 2008 - Accepted 7 January 2008 - First published online 29 February 2008)

The objective of the present study was to examine the effects of dietary $\mathrm{Zn}$ deficiency on the ex vivo cytokine production (IL-2, interferon- $\gamma$ (IFN- $\gamma$ ), IL-6 and IL-10) of isolated thymocytes and splenocytes after mitogenic stimulation with concavalin A and to explore the role of corticosterone in this regulation. Weanling rats were assigned to one of four dietary treatments for 3 weeks: $\mathrm{Zn}$-deficient $(<1 \mathrm{mg} \mathrm{Zn} / \mathrm{kg}$ diet, ad libitum), pair-fed ( $30 \mathrm{mg} \mathrm{Zn/kg} \mathrm{diet,} \mathrm{limited} \mathrm{to} \mathrm{amount} \mathrm{of} \mathrm{feed} \mathrm{as} \mathrm{consumed} \mathrm{by} \mathrm{the} \mathrm{Zn}$-deficient group), marginally $\mathrm{Zn}$-deficient (10 mg $\mathrm{Zn} / \mathrm{kg}$ diet, ad libitum) and control (30 mg Zn/kg diet, ad libitum). Thymocytes and splenocytes were isolated for cytokine stimulation and determination of T-cell phenotypes. Serum corticosterone concentrations were determined by ELISA. The Zn-deficient and pair-fed groups had 14-fold higher serum corticosterone concentrations compared with the marginally $\mathrm{Zn}$-deficient and control groups $(P<0 \cdot 0001)$. The proportions of thymocyte subsets were not altered in the Zn-deficient, pair-fed or marginally Zn-deficient groups; however, thymocyte IL-2 and IL-6 production in these groups was 33-54\% lower compared with the control group $(P<0.05)$. The $\mathrm{Zn}$-deficient group had an $18-28 \%$ lower proportion of new T-cells $\left(\mathrm{TCR} \alpha \beta^{+} \mathrm{CD} 90^{+}\right)$, but no difference in the proportion of new T-cells that were cytotoxic or helper. The $\mathrm{Zn}$-deficient group had a 49-62\% lower production of Th1 cytokines (IL-2), but no difference in the production of Th2 cytokines (IL-6, IL-10) by stimulated splenocytes compared with the pair-fed, marginally $\mathrm{Zn}$-deficient and control groups $(P<0 \cdot 01)$. These results indicate that $\mathrm{Zn}$ status is associated with altered cytokine production, while in vivo corticosterone concentrations are not associated with ex vivo cytokine production.

Zinc deficiency: Cytokines: Spleen: Thymus

The WHO has identified Zn deficiency as one of the leading risk factors of disease, ranking fifth in developing countries and eleventh in developed countries ${ }^{(1)}$. The 2002 WHO report estimates that $\mathrm{Zn}$ deficiency accounts for $18 \%$ of malaria cases, $16 \%$ of lower respiratory tract infections, and $10 \%$ of diarrhoeal disease worldwide. Infants and young children are among the population groups at most risk of $\mathrm{Zn}$ deficiency due to their increased requirements during growth $^{(2)}$.

Prasad $^{(3)}$ has reported that peripheral lymphocytes from Zn-deficient humans produce less IL-2 and interferon (IFN)- $\gamma$ (often referred to as Th1 cytokines) while the Th2 cytokines (IL-6 and IL-10) were not affected. Th1 cytokines initiate a cellular response involving natural killer cells and cytotoxic T-cells which directly combat intracellular infections, but overproduction can lead to autoimmune diseases ${ }^{(4)}$. Th2 cytokines stimulate the humoral response which is more effective at defending against intercellular infections, but overproduction of Th2 cytokines can lead to allergies ${ }^{(4)}$. The balance between Th1 and Th2 cells is controlled mainly by the cytokines they produce. IFN- $\gamma$ inhibits the cytokine production by Th2 cells, and IL-10 inhibits proliferation of Th1 cells ${ }^{(4)}$.

$\mathrm{Zn}$ has been shown to be essential for the expression of IL-2 receptors on lymphocytes ${ }^{(5)}$. Sprietsma ${ }^{(6)}$ has hypothesised that with fewer IL-2 receptors, Th1 cells cannot respond to nor produce the IL-2 they need to proliferate; therefore, the Th2-producing cells and their cytokines begin to dominate. There have been very few reports on the effects of $\mathrm{Zn}$ deficiency on allergic disease; however, $\mathrm{Zn}$-deficient mice had increased broncopulmonary eosinophil inflammation while $\mathrm{Zn}$ supplementation decreased eosinophil numbers ${ }^{(7)}$.

Cytokines also play a role in thymocyte maturation ${ }^{(8)}$; however, the effect of dietary Zn deficiency on thymocyte cytokine production has not been investigated. Theoretically, low IL-2 and IFN- $\gamma$ concentrations in the thymus would limit T-cell proliferation and differentiation, resulting in reduced thymocyte numbers (thymic atrophy) and consequently fewer new T-cells being released into the periphery, thereby leading to lymphopenia and increased susceptibility to disease ${ }^{(8)}$. 
Peripheral IL-6 (a Th2 cytokine) production can stimulate the hypothalamus-pituitary-adrenal axis leading to increased production of corticosterone by the adrenal gland ${ }^{(9)}$. Corticosterone has been shown to suppress production of IFN- $\gamma$ and IL-2 by splenic Th1 cells, thereby pushing the cytokine balance towards $\mathrm{Th} 2^{(10)}$. Thus, we hypothesised that the low $\mathrm{Zn}$ status during dietary $\mathrm{Zn}$ deficiency shifts cytokine production in favour of a Th2 response and this shift in cytokine production is compounded by the higher serum corticosterone concentrations associated with dietary $\mathrm{Zn}$ deficiency.

The objective of the present study was to determine potential differences in the ex vivo cytokine production (IL-2, IFN- $\gamma$, IL-6 and IL-10) of isolated thymocytes and splenocytes after mitogenic stimulation with concanavalin $\mathrm{A}$ (ConA) in Zn-deficient, pair-fed, marginally Zn-deficient and control growing rats. Serum corticosterone concentrations were also measured to explore whether chronic in vivo exposure to corticosterone is associated with altered Th1/Th2 cytokine production ex vivo. Flow cytometric analysis was used to determine the proportion of thymic and splenic T-cell subsets.

\section{Experimental methods}

\section{Animals and diets}

Thirty-two weanling Sprague-Dawley rats (Charles River Laboratories, St Constant, PQ, Canada) were acclimatised for $5 \mathrm{~d}$ and randomly assigned to one of four dietary treatment groups (eight rats per group) for 3 weeks: Zn-deficient $(<1 \mathrm{mg} \mathrm{Zn} / \mathrm{kg})$, marginally Zn-deficient $(10 \mathrm{mg} \mathrm{Zn} / \mathrm{kg})$, nutritionally complete control diet $(30 \mathrm{mg} \mathrm{Zn} / \mathrm{kg}$ ) and pair-fed (fed the control diet, but only the amount of feed as consumed on the previous day by the individual $\mathrm{Zn}$-deficient rat paired to the pair-fed rat). The pair-fed group controls for the effects of undernutrition commonly seen in Zn deficiency. Body weight was measured weekly and feed intake was measured daily.

The experimental diets (based on the AIN-93G formulation and previously described by Lepage et al. ${ }^{(11)}$ ) containing egg white, additional biotin $(2 \mathrm{mg} / \mathrm{kg}$ diet $)$ and potassium phosphate were fed ad libitum, except for the pair-fed group, and distilled water was provided. $\mathrm{Zn}$ content of the diets was verified by atomic absorption analysis (for details of methodology, see 'Zinc analysis'). To avoid Zn recycling and contamination, the rats were housed individually in stainlesssteel hanging cages with mesh bottoms so urine and faeces could drop to the shavings below. In addition, the $\mathrm{Zn}$-deficient group was placed on the upper rows of the cage rack. The rats were maintained in an environment of controlled temperature $\left(21-23^{\circ} \mathrm{C}\right)$, humidity $(55 \%)$ and light cycle (14h light and $10 \mathrm{~h}$ dark). Animal care was provided in accordance with a protocol approved by the University of Manitoba Protocol Management and Review Committee.

\section{Sample collection}

At the end of the feeding trial, the rats were euthanised by $\mathrm{CO}_{2}$ asphyxiation and decapitation. Trunk blood was collected and centrifuged (Beckman TJ-6R Tabletop centrifuge; Beckman Coulter Canada Inc., Mississauga, ON, Canada) to obtain serum and stored at $-80^{\circ} \mathrm{C}$ until analysis. The spleen and thymus were removed aseptically, weighed and then processed immediately. Femurs were removed, cleaned of soft tissue and stored at $-20^{\circ} \mathrm{C}$ until analysis.

Cell preparation. Single-cell suspensions of spleen and thymus were prepared by pressing tissues through nylon screens into Hank's buffered saline supplemented with $10 \mathrm{~mm}$-HEPES, $4 \%$ dextran charcoal-absorbed fetal bovine serum (HyClone, Logan, UT, USA) and $1 \%$ antibiotic/antimycotic at $\mathrm{pH}$ 7.4. Dextran charcoal-absorbed fetal bovine serum was used to limit the amount of external steroids that the splenocytes are exposed to during cell preparation. Erythrocytes in the spleen cell suspensions were lysed using

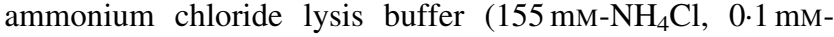
EDTA and $10 \mathrm{~mm}-\mathrm{KHCO}_{3}$ at $\mathrm{pH}$ 7.2). Cell concentration and viability were determined using trypan blue dye exclusion on an AO Bright-Line Hemacytometer (American Optical Corporation, Buffalo, NY, USA).

Cytokine stimulation. Thymocytes and splenocytes $\left(3 \times 10^{6}\right.$ cells) from each rat were re-suspended in $3 \mathrm{ml}$ sterile Roswell Park Memorial Institute (RPMI)-1640 supplemented with $10 \mathrm{mM}$-HEPES, $10 \mathrm{~mm}$-sodium bicarbonate, $1 \mathrm{~mm}$-sodium pyruvate, $2 \mathrm{~mm}$-glutamine, $0 \cdot 1 \mathrm{~mm}$-non-essential amino acids, $50 \mu \mathrm{M}$-2-mercaptoethanol, $1 \%$ antibiotic/antimycotic and $5 \%$ fetal bovine serum at $\mathrm{pH} 7 \cdot 2$. ConA $(300 \mu \mathrm{l}$ of $2.5 \mu \mathrm{g} / \mathrm{ml}$ working solution) was added and cells were incubated at $37^{\circ} \mathrm{C}$ with $5 \% \mathrm{CO}_{2}$ for $48 \mathrm{~h}$. Cells not exposed to mitogen were included as a control to verify that mitogenic stimulation increased cytokine production. After $48 \mathrm{~h}$ incubation, cells were centrifuged for $5 \mathrm{~min}$ at $300 \mathrm{~g}$. Cell-culture supernatant fractions were collected and stored at $-80^{\circ} \mathrm{C}$ until analysis.

\section{Outcome measurements}

Zinc analysis. After obtaining wet and dry weights, femurs and diet samples were wet-ashed using trace element-grade nitric acid as described previously ${ }^{(12)}$. After appropriate dilution of digests or serum with double-deionised water, $\mathrm{Zn}$ concentration was determined by atomic absorption spectrometry (Varian Spectra AA; Varian Mississauga, ON, Canada). Bovine liver standard reference material $1577 \mathrm{~b}$ (US Department of Commerce, National Institute of Standards and Technology, Gaithersburg, MD, USA) and human serum reference (BioRad Laboratories, Irvine, CA, USA) were used as quality controls.

Determination of T-lymphocyte subpopulations: antibodies. Monoclonal antibodies for T-cell receptor (TCR) $\alpha \beta$ (phycoerythrin (PE) label, clone $\mathrm{R} 73$, isotype mouse $\operatorname{IgG}_{1, \mathrm{k}}$ ), CD90 (fluorescein isothiocyanate (FITC) label, Thy1.1, clone OX-7, isotype mouse $\mathrm{IgG}_{1, \mathrm{k}}$ ), CD4 (PE-Cy5 label, clone $\mathrm{OX}-35$, isotype mouse $\mathrm{IgG}_{2 \mathrm{a}, \mathrm{k}}$ ) and $\mathrm{CD} 8$ (biotin, clone $\mathrm{OX}-8$, isotype mouse $\mathrm{IgG}_{1, \mathrm{k}}$ ) were obtained from BD Pharmingen (Mississauga, Ontario, Canada). Streptavidin-PECy7 conjugate was used to label the biotinylated antibodies.

Determination of T-lymphocyte subpopulations: cell labelling and flow cytometry. Cells from each dietary treatment group and tissue were washed and placed in label buffer (PBS containing $23 \mathrm{~mm}$-sodium azide and $2 \%$ fetal bovine serum, $\mathrm{pH} 7.4$ ) at $4^{\circ} \mathrm{C}$ at a concentration of $1 \times 10^{6}$ cells $/ \mathrm{ml}$. The biotinylated anti-CD8 antibody was added first, incubated for $30 \mathrm{~min}$ at $4{ }^{\circ} \mathrm{C}$, followed by a wash step. Then, the directly conjugated antibodies and streptavidin-PE-Cy7 were added, incubated as previously described, followed by a wash step. Samples 
were re-suspended in PBS containing $50 \%$ fetal bovine serum. Ethanol $(70 \%)$ was added drop-wise while gently mixing to a final concentration of $50 \%$. Cells were stored overnight at $4^{\circ} \mathrm{C}$ and analysed on the flow cytometer the following morning.

Flow cytometry analysis was performed on a Beckman Coulter EPICS ALTRA (Beckman Coulter, Mississauga, ON, Canada) high-speed cell sorter with laser excitation tuned to $488 \mathrm{~nm}(65 \mathrm{~mW})$ and UV. Figs. 1 and 2 depict representative flow cytometry plots from thymus and spleen, respectively. Forward $v$. side-scatter histograms were used to gate on intact lymphoid cells. The fluorescence signals were separated with the standard dichotic long-pass filters provided with the instrument and detected through $525 \mathrm{~nm}$ (FITC), $575 \mathrm{~nm}$ (PE), $675 \mathrm{~nm}$ (PE-Cy5) and $735 \mathrm{~nm}$ (PE-Cy7) bandpass filters. The data were collected in list-mode format with the subsequent analyses based on 20000 cells satisfying the light scatter gate for $\mathrm{CD}^{+}$in thymocytes, or 20000 cells satisfying the light scatter gate for $\mathrm{TCR} \alpha \beta^{+} \mathrm{CD} 90^{-}$in splenocytes using the EXPO32 MultiCOMP MFA software (Beckman Coulter) provided with the instrument. Flurochrome-isotype-matched controls were prepared to assess autofluorescence and non-specific binding, while singlecolour samples were employed to adjust colour compensation.

Cytokine analysis. IL-2, IL-6, IL-10 and IFN- $\gamma$ in cell-culture supernatant fractions were determined simultaneously using a cytometric bead array kit (LINCO Research, St Charles, MO, USA). The standard curves were 4.88 to $20000 \mathrm{pg} / \mathrm{ml}$. The samples were analysed using the Luminex ${ }^{\mathrm{TM}} 100$ instrument (Luminex Corporation, Austin, TX, USA).

Corticosterone concentration. Serum corticosterone concentrations were determined using an enzyme immunoassay kit (Assay Designs, Ann Arbor, MI, USA).

\section{Statistical analyses}

Data were analysed by one-way ANOVA using the general linear models procedure or repeated-measures ANOVA (SAS software release 9.1; SAS Institute, Cary, NC, USA) as appropriate. Significant differences among means were determined using Duncan's multiple-range test. Differences were considered significant at $P<0.05$.

\section{Results}

Feed intake

After only $3 \mathrm{~d}$ of treatment, the Zn-deficient group consumed $17 \%$ less feed per $\mathrm{d}$ than the control and marginally $\mathrm{Zn}$ deficient groups (Fig. 3). By day 4, the Zn-deficient group was consuming $54 \%$ less feed per $d$ than the marginally $\mathrm{Zn}$-deficient and control groups and this continued until the end of the study. The marginally Zn-deficient group did not exhibit any signs of anorexia throughout the study.

\section{Body weight}

The marginally Zn-deficient group had the same body weight (Fig. 4), weight gain and feed efficiency ratio (Table 1) as the control group throughout the study. The $\mathrm{Zn}$-deficient group weighed 22, 40 and $50 \%$ less than the control group at weeks 1,2 and 3, respectively. Of the $35.8 \mathrm{~g}$ of total weight gained by
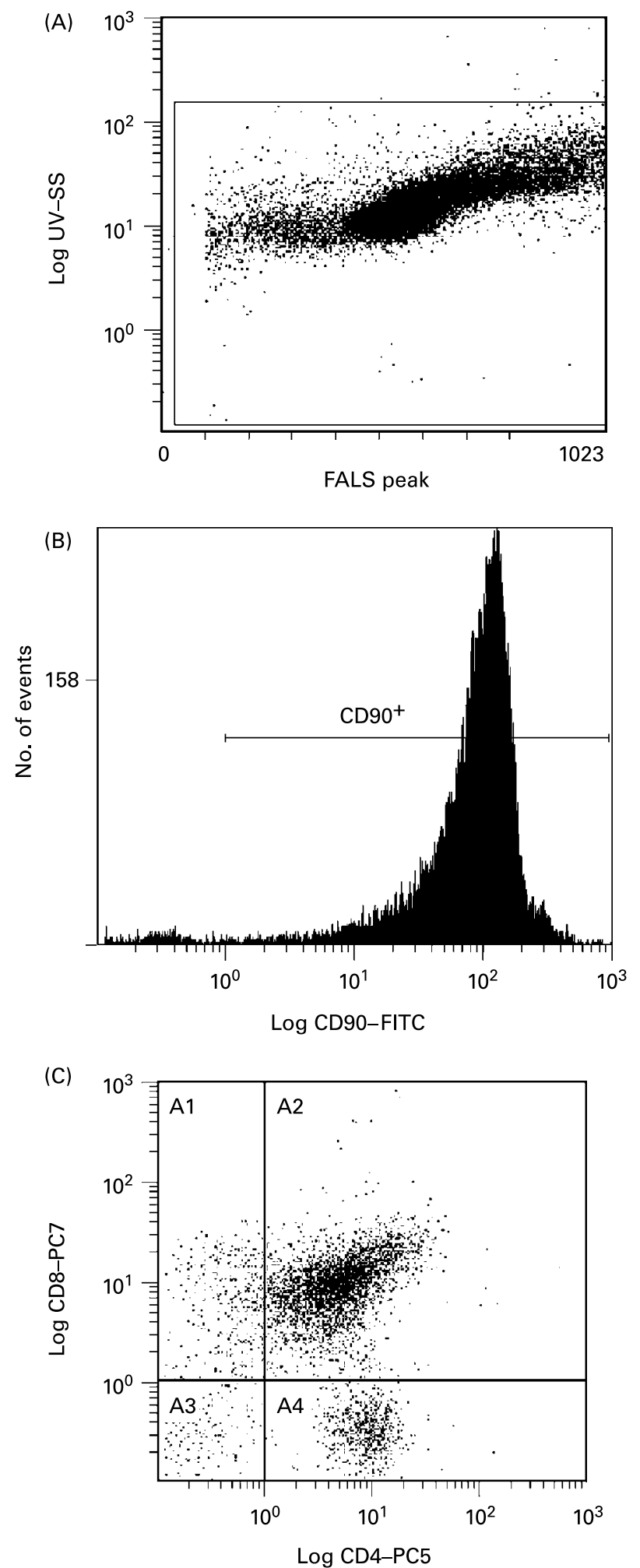

Fig. 1. Representative flow cytometry plot of thymocytes. Definition of lymphocytes (CELLS) by forward $v$. side scatter (A); definition of CD90 binding after gating on CELLS (B); CD8 and CD4 binding after gating on $\mathrm{CD}^{+} 0^{+}$and CELLS (C). SS, side scatter; FALS, forward angle light scatter; FITC, fluorescein isothiocyanate; $\mathrm{PC}$, phycoerythrin-cyanine; $\mathrm{A} 1, \mathrm{CD} 90^{+} \mathrm{CD} 8^{+} \mathrm{CD} 4^{-}$; $\mathrm{A} 2, \mathrm{CD} 90^{+} \mathrm{CD}^{+}{ }^{+} \mathrm{CD} 4^{+}$; $\mathrm{A} 3, \mathrm{CD}_{90}{ }^{+} \mathrm{CD}^{-} \mathrm{CD}^{-}$; $\mathrm{A} 4, \mathrm{CD} 0^{+} \mathrm{CD} 8^{-} \mathrm{CD}^{+}$. 

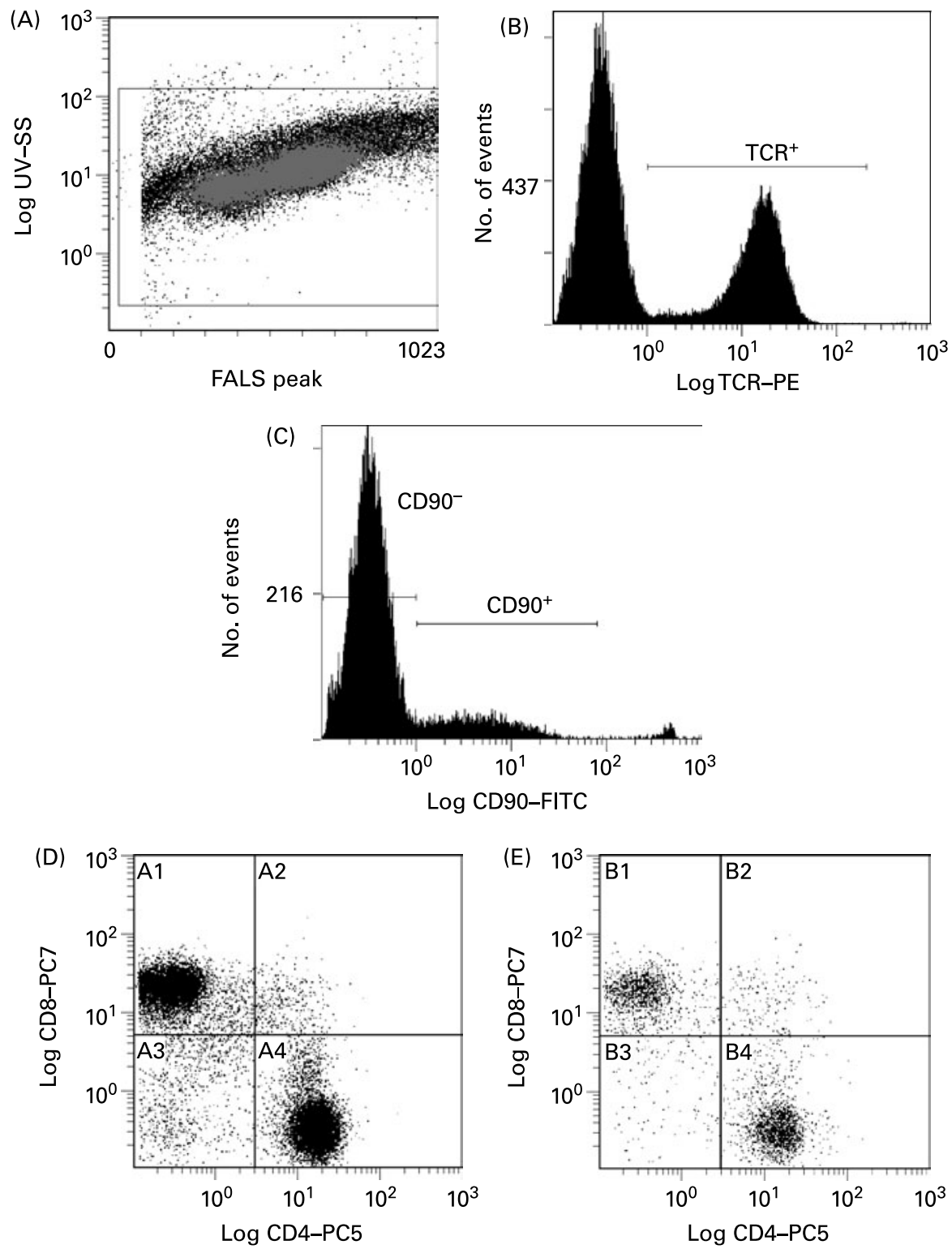

Fig. 2. Representative flow cytometry plot of splenocytes. Definition of lymphocytes (CELLS) by forward $v$. side scatter (A); definition of T-cell receptor (TCR) $\alpha \beta$ binding after gating on CELLS (B); definition of CD90 binding after gating on TCR $\alpha \beta^{+}$and CELLS (C); CD8 and CD4 binding after gating on CD90 ${ }^{-}$, TCR $\alpha \beta^{+}$and CELLS (D); CD8 and CD4 binding after gating on CD90 ${ }^{+}, \mathrm{TCR} \alpha \beta^{+}$and CELLS (E). SS, side scatter; FALS, forward angle light scatter; PE, phycoerythrin; FITC fluorescein isothiocyanate; PC; phycoerythrin-cyanine; $\mathrm{A} 1, \mathrm{TCR} \alpha \beta^{+} \mathrm{CD} 90^{-} \mathrm{CD} 8^{+} \mathrm{CD} 4^{-} ; \mathrm{A} 2, \mathrm{TCR} \alpha \beta^{+} \mathrm{CD} 90^{-} \mathrm{CD} 8^{+} \mathrm{CD} 4^{+} ; \mathrm{A} 3, \mathrm{TCR} \alpha \beta^{+} \mathrm{CD} 90^{-} \mathrm{CD} 8^{-} \mathrm{CD} 4^{-} ; \mathrm{A} 4$ TCR $\alpha \beta^{+} \mathrm{CD} 90^{-} \mathrm{CD}^{-} \mathrm{CD} 4^{+}$; B1, TCR $\alpha \beta^{+} \mathrm{CD} 90^{+} \mathrm{CD} 8^{+} \mathrm{CD} 4^{-}$; B2, TCR $\alpha \beta^{+} \mathrm{CD} 90^{+} \mathrm{CD} 8^{+} \mathrm{CD} 4^{+}$; B3, TCR $\alpha \beta^{+} \mathrm{CD} 90^{+} \mathrm{CD} 8^{-} \mathrm{CD} 4^{-}$; B4, TCR $\alpha \beta^{+} \mathrm{CD} 90^{+} \mathrm{CD} 8^{-} \mathrm{CD} 4^{+}$.

the $\mathrm{Zn}$-deficient rats, $25.5 \mathrm{~g}$ was gained during week 1 and only $10 \cdot 3 \mathrm{~g}$ was gained during the remaining 2 weeks, while the marginally $\mathrm{Zn}$-deficient and control groups gained $61 \cdot 0 \mathrm{~g}$ in week 1 , $56.5 \mathrm{~g}$ in week 2 and $54.2 \mathrm{~g}$ in week 3 . The pair-fed animals weighed more than the $\mathrm{Zn}$-deficient rats at each week due to more efficient conversion of feed into growth as indicated by a lower feed efficiency ratio.

\section{Serum and femur zinc}

Femur and serum $\mathrm{Zn}$ concentrations were reduced $78-83 \%$ in the $\mathrm{Zn}$-deficient and 38-40\% in the marginally $\mathrm{Zn}$-deficient rats compared with the control rats (Table 1). Also, serum and femur $\mathrm{Zn}$ concentrations were $15 \%$ lower in the pairfed group compared with the control group.

\section{Lymphoid organ weight}

One of the classic characteristics of $\mathrm{Zn}$ deficiency is reduced lymphoid organ weight. The thymus and spleen weights of the Zn-deficient and pair-fed rats were not significantly different from each other, but they were 36-53\% lower than the marginally Zn-deficient and control animals (Tables 2 and 3). When the thymus and spleen weights were corrected for body weight, there were no differences among the dietary treatments. 


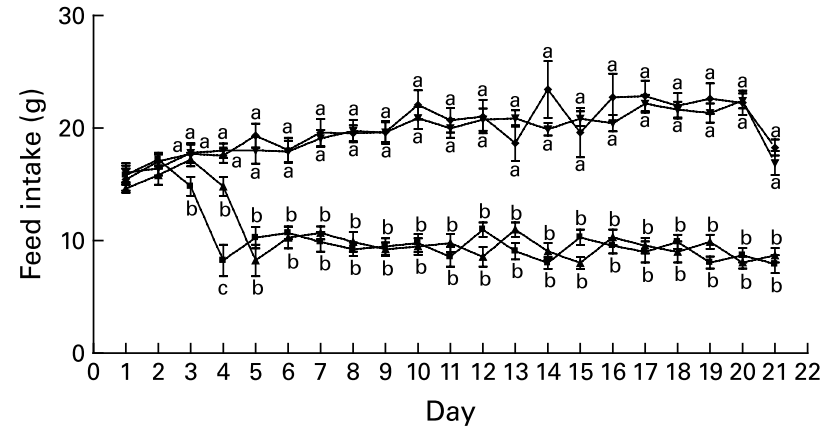

Fig. 3. Feed intake of Zn-deficient ( $\mathbf{\square})$, marginally $Z n$-deficient $(\mathbf{\nabla})$, pair-fed $(\boldsymbol{\Lambda})$ and control $(\bullet)$ rats over $21 \mathrm{~d}$. Values are means for eight rats per group, with their standard errors represented by vertical bars. There were significant main effects of diet $(P<0.0001)$, time $(P<0.0001)$ and diet $\times$ time interaction $(P<0.0001)$. ${ }^{\mathrm{a}, \mathrm{b}}$ At each time point, mean values with unlike letters were significantly different $(P<0.05)$. The values for $Z n$-deficient and pair-fed rats (lower lines) and values for marginally $\mathrm{Zn}$-deficient and control rats (upper lines) are overlapping.

\section{Thymocyte subset proportions}

There were no differences among the dietary treatment groups in the proportion of thymocyte subsets (pro, pre, cytotoxic and helper).

\section{Splenocyte T-cell subset numbers}

The Zn-deficient group had an 18-28\% lower proportion of splenic new T-cells and a 3-5\% higher proportion of mature T-cells compared with the pair-fed, marginally Zn-deficient and control groups (Table 3). Of the new and mature T-cells, there were no differences in the proportion of cytotoxic and helper T-cells among dietary treatment groups, therefore, both cytotoxic $\left(\mathrm{CD}^{+}\right)$and helper $\left(\mathrm{CD} 4^{+}\right)$ lymphocytes contributed equally to the changes in the total new $\left(\mathrm{CD} 90^{+}\right)$and mature $\left(\mathrm{CD} 90^{-}\right)$T-cell populations.

\section{Serum corticosterone concentration}

The $\mathrm{Zn}$-deficient and pair-fed rats had a 14-fold higher serum corticosterone concentration compared with the marginally Zn-deficient and control rats (Fig. 5).

\section{Cytokine concentrations after mitogenic stimulation}

Mitogenic stimulation of thymocytes from the $\mathrm{Zn}$-deficient, pair-fed and marginally Zn-deficient animals resulted in

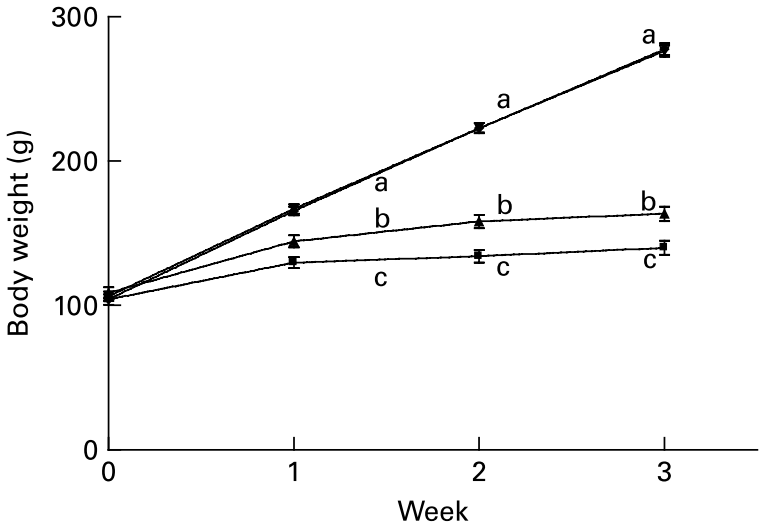

Fig. 4. Weekly body weight of Zn-deficient ( $\mathbf{\square})$, marginally Zn-deficient $(\boldsymbol{\nabla})$, pair-fed $(\boldsymbol{\Delta})$ and control $(\bullet)$ rats. Values are means for eight rats per group, with their standard errors represented by vertical bars. There were significant main effects of diet $(P<0.0001)$, time $(P<0.0001)$ and diet $\times$ time interaction $(P<0.0001) .{ }^{\mathrm{a}, \mathrm{b}, \mathrm{c}}$ At each time point, mean values with unlike letters were significantly different $(P<0.05)$. The values for marginally $\mathrm{Zn}$-deficient and control rats are overlapping.

$33-54 \%$ lower concentrations of IL-2 and IL-6 in cell-culture supernatant fractions compared with the control group (Fig. 6). There were no differences among the dietary treatment groups in the concentration of IFN- $\gamma$ and IL-10 produced by thymocytes after stimulation.

Zn-deficient splenocytes produced 49-62\% less IL-2 compared with those from the pair-fed, marginally $\mathrm{Zn}$-deficient and control rats, and $63-76 \%$ less IFN- $\gamma$ compared with the pair-fed and marginally $\mathrm{Zn}$-deficient groups in response to ConA. IL-6 and IL-10 concentrations were not different among dietary treatment groups, and IL-10 concentrations from stimulated splenocytes were not different from unstimulated splenocytes.

\section{Discussion}

Researchers studying the effects of dietary Zn deficiency typically include a pair-fed group (identified as pair-fed in the present study) to separate out the effects of malnutrition from $\mathrm{Zn}$ deficiency. Because severe $\mathrm{Zn}$ deficiency in humans is rare, a marginally $\mathrm{Zn}$-deficient group, which was fed a diet containing a third of the recommended dietary $\mathrm{Zn}$, was also included in the present study. The marginally Zn-deficient group had reduced Zn status compared with both the control and pair-fed groups; however,

Table 1. Feed intake and zinc status of zinc-deficient (ZD), marginally zinc-deficient (MZD), pair-fed (PF) and control rats* (Mean values with their standard errors for eight rats per group)

\begin{tabular}{|c|c|c|c|c|c|c|c|c|}
\hline \multirow[t]{2}{*}{ Dietary group... } & \multicolumn{2}{|c|}{ ZD } & \multicolumn{2}{|c|}{ PF } & \multicolumn{2}{|c|}{ MZD } & \multicolumn{2}{|c|}{ Control } \\
\hline & Mean & SE & Mean & SE & Mean & SE & Mean & SE \\
\hline Total weight gain (g) & $35 \cdot 8^{\mathrm{c}}$ & $1 \cdot 7$ & $54 \cdot 9^{\mathrm{b}}$ & $3 \cdot 9$ & $170 \cdot 1^{\mathrm{a}}$ & $3 \cdot 3$ & $173 \cdot 3^{a}$ & $4 \cdot 7$ \\
\hline Feed efficiency ratio† & $6 \cdot 1^{a}$ & 0.3 & $4 \cdot 2^{b}$ & 0.2 & $2 \cdot 4^{\mathrm{C}}$ & 0.1 & $2 \cdot 4^{\mathrm{C}}$ & $0 \cdot 1$ \\
\hline Serum Zn $(\mu \mathrm{mol} / \mathrm{l})$ & $5 \cdot 2^{d}$ & 0.3 & $26 \cdot 2^{b}$ & 1.2 & $18 \cdot 5^{\mathrm{c}}$ & 0.9 & $30 \cdot 6^{a}$ & $1 \cdot 3$ \\
\hline Femur $\mathrm{Zn}(\mu \mathrm{mol} / \mathrm{g}$ dry bone $)$ & $1 \cdot 0^{\mathrm{d}}$ & 0.1 & $4 \cdot 1^{b}$ & 0.1 & $3 \cdot 0^{c}$ & 0.1 & $4 \cdot 8^{\mathrm{a}}$ & 0.1 \\
\hline
\end{tabular}

${ }^{a, b, c, d}$ Mean values with unlike superscript letters were significantly different $(P<0.05)$.

${ }^{\star}$ For details of diets and procedures, see Experimental methods.

†Feed efficiency ratio $=$ total feed intake $(\mathrm{g}) /$ total weight gain $(\mathrm{g})$. 
Table 2. Thymus weight and proportion of thymocyte subsets from zinc-deficient (ZD), marginally zinc-deficient (MZD), pair-fed (PF) and control rats* $†$ (Mean values with their standard errors for eight rats per group)

\begin{tabular}{|c|c|c|c|c|c|c|c|c|}
\hline \multirow[t]{2}{*}{ Dietary group... } & \multicolumn{2}{|c|}{ ZD } & \multicolumn{2}{|c|}{ PF } & \multicolumn{2}{|c|}{ MZD } & \multicolumn{2}{|c|}{ Control } \\
\hline & Mean & SE & Mean & SE & Mean & SE & Mean & SE \\
\hline Thymus weight (mg) & $418^{\mathrm{b}}$ & $18 \cdot 3$ & $528^{b}$ & $20 \cdot 6$ & $882^{\mathrm{a}}$ & $35 \cdot 3$ & $828^{a}$ & $72 \cdot 6$ \\
\hline Relative thymus weight (mg/g body weight) & 3.0 & 0.1 & $3 \cdot 2$ & 0.1 & $3 \cdot 2$ & 0.1 & 3.0 & 0.2 \\
\hline \multicolumn{9}{|l|}{ Proportion of thymocyte subsets (\%) } \\
\hline Pro-T cell & 3.4 & 0.3 & $3 \cdot 3$ & 0.3 & $3 \cdot 0$ & 0.3 & $3 \cdot 1$ & 0.4 \\
\hline Pre-T cell & 79.9 & 0.9 & 79.5 & 1.6 & 79.6 & $2 \cdot 3$ & 78.7 & $2 \cdot 0$ \\
\hline Helper & $9 \cdot 3$ & 0.7 & $10 \cdot 4$ & $1 \cdot 1$ & 11.0 & 1.5 & $12 \cdot 2$ & 1.7 \\
\hline
\end{tabular}

${ }^{\mathrm{a}, \mathrm{b}}$ Mean values with unlike superscript letters were significantly different $(P<0.05)$.

${ }^{*}$ For details of diets and procedures, see Experimental methods.

† Pro-T cells identified as $\mathrm{CD} 90^{+} 4^{-} 8^{-}$, Pre-T cells identified as $\mathrm{CD} 90^{+} 4^{+} 8^{+}$, cytotoxic identified as $\mathrm{CD}^{+} 0^{+} 4^{-} 8^{+}$and helper identified as $\mathrm{CD} 90^{+} 4^{+} 8^{-}$by flow cytometry.

Table 3. Spleen weight and T-cell subset numbers of zinc-deficient (ZD), marginally zinc-deficient (MZD), pair-fed (PF) and control rats ${ }^{*} \dagger$ (Mean values with their standard errors for eight rats per group)

\begin{tabular}{|c|c|c|c|c|c|c|c|c|}
\hline \multirow[t]{2}{*}{ Dietary group... } & \multicolumn{2}{|c|}{ ZD } & \multicolumn{2}{|c|}{ PF } & \multicolumn{2}{|c|}{ MZD } & \multicolumn{2}{|c|}{ Control } \\
\hline & Mean & SE & Mean & SE & Mean & SE & Mean & SE \\
\hline Spleen weight (mg) & $377^{\mathrm{b}}$ & $14 \cdot 2$ & $402^{\mathrm{b}}$ & $14 \cdot 1$ & $744^{\mathrm{a}}$ & $40 \cdot 4$ & $747^{\mathrm{a}}$ & $26 \cdot 3$ \\
\hline Relative spleen weight (mg/g body weight) & $2 \cdot 7$ & 0.1 & 2.5 & 0.1 & $2 \cdot 7$ & 0.1 & $2 \cdot 7$ & 0.1 \\
\hline Total T-cells (\%) & $32 \cdot 7$ & 1.6 & 34.5 & 1.6 & $32 \cdot 7$ & $2 \cdot 4$ & $28 \cdot 1$ & $2 \cdot 4$ \\
\hline Total new T-cells (\% of total T-cells) & $9.6^{\mathrm{b}}$ & 0.4 & $11.9^{\mathrm{a}}$ & 0.7 & $13 \cdot 4^{\mathrm{a}}$ & 1.0 & $12 \cdot 8^{\mathrm{a}}$ & 0.7 \\
\hline New cytotoxic ( $\%$ of total new T-cells) & 36.7 & 1.3 & 36.8 & 1.1 & 38.8 & 1.5 & 37.0 & 1.2 \\
\hline New helper (\% of total new T-cells) & 49.8 & 0.8 & 49.4 & 0.8 & 48.6 & $1 \cdot 0$ & 49.0 & 1.2 \\
\hline Total mature T-cells (\% of total T-cells) & $88 \cdot 3^{\mathrm{a}}$ & 0.3 & $86.0^{\mathrm{b}}$ & 0.8 & $84.0^{\mathrm{b}}$ & 1.0 & $84.0^{\mathrm{b}}$ & 0.7 \\
\hline Mature cytotoxic ( $\%$ of total mature T-cells) & 35.7 & $1 \cdot 2$ & 39.4 & 1.6 & $40 \cdot 1$ & $1 \cdot 2$ & 37.3 & $2 \cdot 1$ \\
\hline Mature helper ( $\%$ of total mature T-cells) & 57.9 & 1.5 & 54.5 & 1.9 & $56 \cdot 1$ & $2 \cdot 1$ & 54.4 & 1.4 \\
\hline
\end{tabular}

a,b Mean values with unlike superscript letters were significantly different $(P<0.05)$.

${ }^{*}$ For details of diets and procedures, see Experimental methods.

† Total T-cells identified as T-cell receptor (TCR) $\alpha \beta^{+}$, total new T-cells identified as TCR $\alpha \beta^{+} \mathrm{CD} 90^{+}$, new cytotoxic identified as TCR $\alpha \beta^{+} \mathrm{CD} 90^{+} 4^{-} 8^{+}$, new helper identified as TCR $\alpha \beta^{+} \mathrm{CD} 90^{+} 4^{+} 8^{-}$, total mature T-cells identified as TCR $\alpha \beta^{+} \mathrm{CD} 90^{-}$, mature cytotoxic identified as TCR $\alpha \beta^{+} \mathrm{CD} 90^{-} 4^{-} 8^{+}$and mature helper identified as TCR $\alpha \beta^{+-}$ $\mathrm{CD} 90^{-} 4^{+} 8^{-}$by flow cytometry.

it did not exhibit any signs of anorexia or impaired growth compared with the control group (Table 1, Fig. 3, Fig. 4). The pair-fed animals had stunting malnutrition similar to the $\mathrm{Zn}$-deficient group; however, their $\mathrm{Zn}$ status was greater than both the $\mathrm{Zn}$-deficient and marginally $\mathrm{Zn}$-deficient rats. Therefore, the present study was able to examine the effects of reduced $\mathrm{Zn}$ status without malnutrition as well as being able to separate the effects of $\mathrm{Zn}$ status from malnutrition.

The major finding in the present study was that the altered mitogen-stimulated cytokine production ex vivo by thymocytes and splenocytes from Zn-deficient, pair-fed and marginally $\mathrm{Zn}$-deficient rats does not follow the same pattern as serum corticosterone concentrations. The Zn-deficient and pair-fed group had higher serum corticosterone concentrations compared with the marginally $\mathrm{Zn}$-deficient and control groups (Fig. 5); however, the Zn-deficient, pair-fed and marginally Zn-deficient groups had lower IL-2 and IL-6 cytokine production by ConA-stimulated thymocytes (not reported previously) while only the Zn-deficient group had lower IL2 cytokine production by ConA-stimulated splenocytes compared with the control group (Fig. 6). Due to the inclusion of the pair-fed and marginally Zn-deficient groups, the present study was able to separate out the effects of elevated corticosterone concentrations from the effects of
$\mathrm{Zn}$ deficiency. These results indicate that in vivo serum corticosterone concentrations do not appear to permanently 'program' ex vivo lymphocyte responses to ConA.

Thymocytes from the Zn-deficient, pair-fed and marginally $\mathrm{Zn}$-deficient groups produced similar cytokine profiles (lower concentrations of IL- 2 and IL- 6 compared with the control

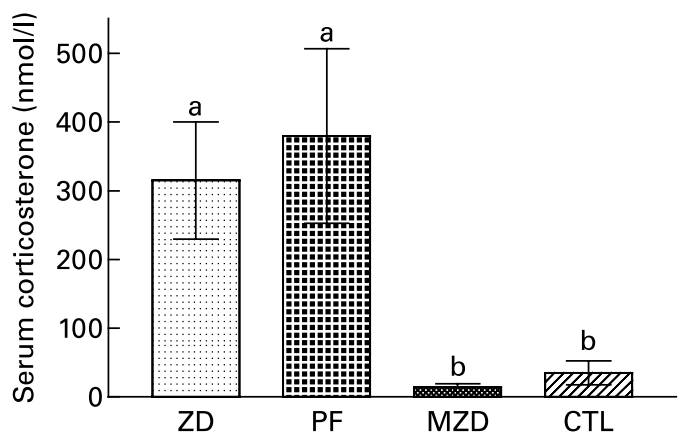

Fig. 5. Serum corticosterone concentrations of Zn-deficient (ZD), pair-fed (PF), marginally $\mathrm{Zn}$-deficient (MZD) and control (CTL) rats. Values are means for eight rats per group, with their standard errors represented by vertical bars. ${ }^{a, b}$ Mean values with unlike letters were significantly different $(P<0.05)$. 
(A)

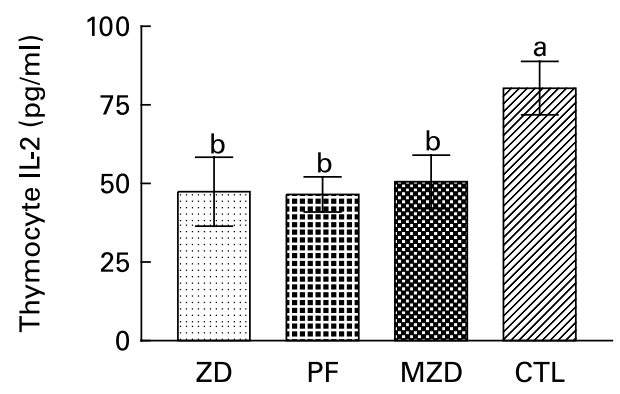

(C)

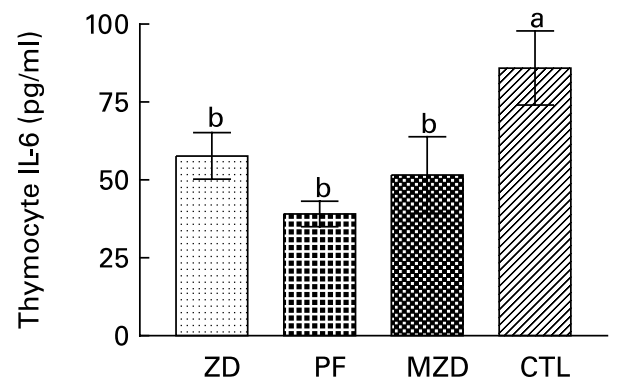

(E)

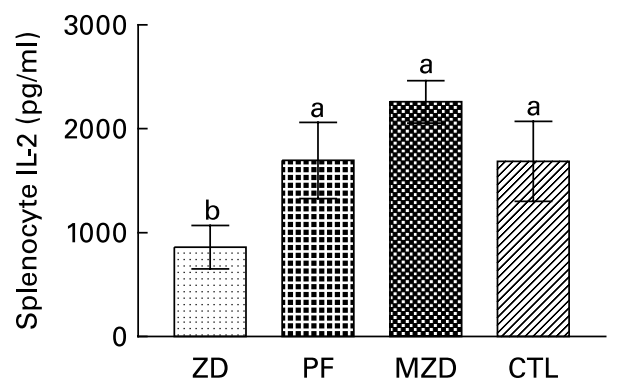

(G)

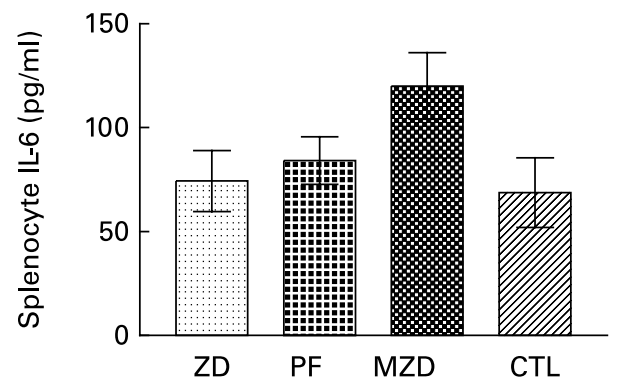

(B)

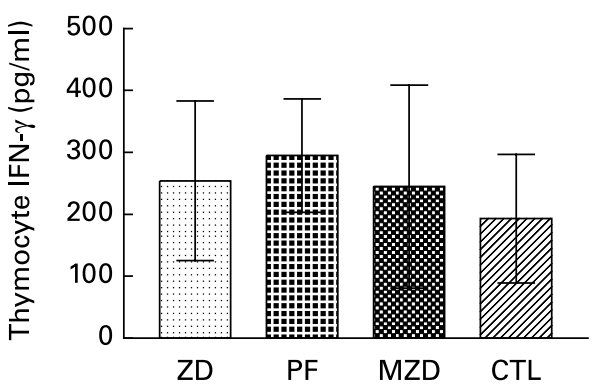

(D)

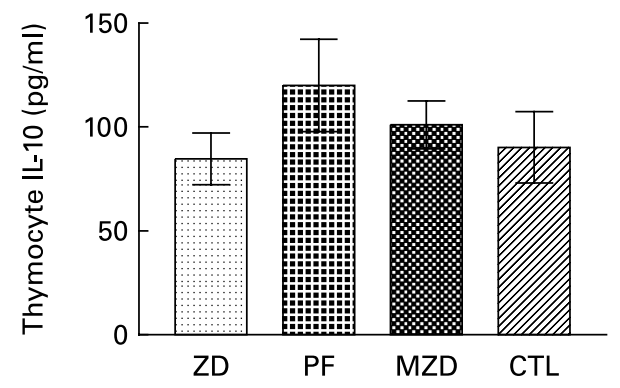

(F)

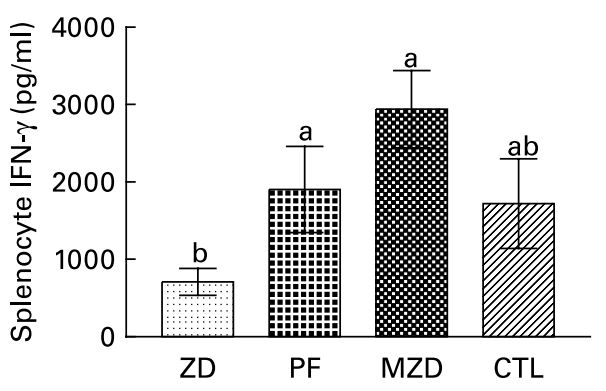

(H)

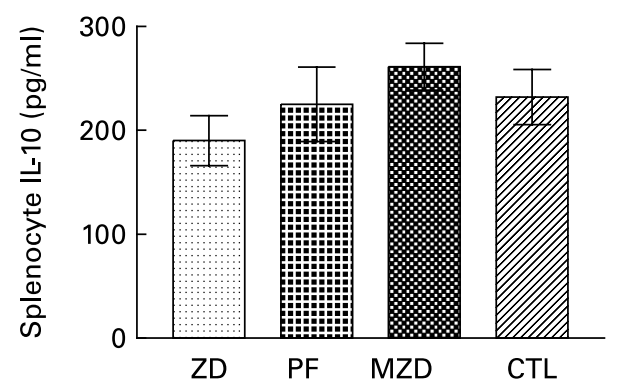

Fig. 6. Supernatant fraction cytokine concentrations from concanvalin A-stimulated thymocytes (A, B, C, D) and splenocytes (E, F, G, H) from Zn-deficient (ZD), pair-fed (PF), marginally Zn-deficient (MZD) and control (CTL) rats. Thymocytes and splenocytes were stimulated ex vivo with concanvalin $A$ for $48 \mathrm{~h}$ and cytokine production was measured as described in Experimental methods. Values are means ( $n 7$ for thymocytes; $n 8$ for splenocytes) with their standard errors represented by vertical bars, with the following exceptions where data points were removed because they were greater than three standard deviations from the mean: PF thymocyte IL-2, $n 6$ (value removed $=226 \cdot 8$ ); PF splenocyte IL-6, $n 7$ (value removed $=364.5$ ). ${ }^{\text {a,b }}$ Mean values with unlike letters were significantly different $(P<0.05)$. There were no differences among the dietary treatment groups in the unstimulated cytokine concentrations. Unstimulated thymocyte cytokine concentrations were as follows: IL-2 = 7.0 (SE 1.3) pg/ml; IL-6 = 17.3 (SE 4.2) pg/ml; IL-10=19.8 (SE 2.4) pg/ml; interferon (IFN)- $\gamma=11.5$ (SE 3.0) pg/ml. Unstimulated splenocyte cytokine concentrations were as follows: IL-2 = 16.8 (SE 1.7$) \mathrm{pg} / \mathrm{ml} ; \mathrm{IL}-6=45 \cdot 2$ (SE 4.7$) \mathrm{pg} / \mathrm{ml} ; \mathrm{IL}-10=286.9$ (SE 14.3$) \mathrm{pg} / \mathrm{ml} ; \mathrm{IFN}-\gamma=5.5$ (SE 0.9) $\mathrm{pg} / \mathrm{ml}$.

group) (Fig. 5). The Zn-deficient, marginally Zn-deficient, and even the pair-fed group had lower Zn status (lower serum and femur $\mathrm{Zn}$ concentrations) compared with the control group; therefore, a possible interpretation of these results is that cytokine production by thymocytes is very sensitive to small changes in dietary $\mathrm{Zn}$. In the periphery, IL-2 and IL-6 are identified as Th1 and Th2 cytokines, respectively, so it would appear that in the thymus there is not a shift in the 
Th1/Th2 balance. However, in the thymus, both IL-2 and IL-6 play a role in stimulating thymocyte proliferation and differentiation ${ }^{(8)}$. Less IL-2 and IL-6 production indicates that thymocytes from the Zn-deficient, pair-fed and marginally $\mathrm{Zn}$-deficient animals are receiving fewer signals to proliferate and differentiate compared with control, suggesting that thymocyte numbers should be negatively affected. In fact, blocking the IL-2 receptor in rat fetal thymus organ cultures results in $21 \%$ fewer thymocytes ${ }^{(13)}$ and IL-6-deficient mice have $20-40 \%$ fewer thymocytes and peripheral T-cells ${ }^{(14)}$. On a per $g$ basis, the $\mathrm{Zn}$-deficient and pair-fed animals were able to maintain thymocyte numbers (data not shown) despite their cytokine profile, most probably because they are not growing as quickly as the marginally $\mathrm{Zn}$-deficient and control rats. However, growth of the marginally Zn-deficient animals was similar to that of the control animals and yet the marginally $\mathrm{Zn}$-deficient rats were able to maintain thymocyte numbers despite lower concentrations of IL-2 and IL-6 being produced. A possible explanation is that there is a redundancy in the function of these cytokines and other cytokines are able to maintain proliferation and differentiation when IL-2 and IL- 6 concentrations are low ${ }^{(8)}$.

$\mathrm{Zn}$-deficient rats had a lower proportion of splenic new T-cells (both helper and cytotoxic) compared with the pairfed, marginally Zn-deficient and control rats (Table 2). New $\mathrm{T}$-cells are essential to ensure $\mathrm{T}$-cell repertoire diversity ${ }^{(15)}$, thus over time the Zn-deficient rat may become more vulnerable to infection. We have previously reported that $\mathrm{Zn}$-deficient rats have a lower proportion of new T-cells $\left(\mathrm{TCR} \alpha \beta^{+} \mathrm{CD} 90^{+}\right)$; however, it was not clear whether the lower proportion was due to a lower number of new helper T-cells, a lower number of new cytotoxic T-cells or both ${ }^{(16)}$. The present study builds on this previous work by reporting that there was a specific effect of severely reduced $\mathrm{Zn}$ status on the proportion of both new helper T-cells and new cytotoxic T-cells (Table 3). The production of new helper and new cytotoxic T-cells could also be adversely affected by thymulin (a hormone involved in thymocyte development), as in $\mathrm{Zn}$ deficiency there is insufficient $\mathrm{Zn}$ to sustain thymulin in its active form ${ }^{(17)}$

Only Zn-deficient splenocytes produced less IL-2 compared with control, indicating a specific effect of severe $\mathrm{Zn}$ deficiency on peripheral T-cell cytokine production. These results support previous findings in $\mathrm{Zn}$-deficient humans ${ }^{(18)}$ and provide a possible explanation for the lower number of new peripheral T-cells. New T-cells respond to cytokine proliferation signals from IL-2 without any other stimulus and this response is lost as T-cells develop in the periphery ${ }^{(19)}$. This could explain why the new T-cells would be more vulnerable to low IL-2 concentrations than the mature T-cells, resulting in a lower proportion of the new T-cells but not the mature T-cells. IFN- $\gamma$ pushes Th1 cells to produce their cytokines $^{(4)}$. A lack of a difference in splenocyte IL-2 production among the pair-fed, marginally $\mathrm{Zn}$-deficient and control rats may be explained by the higher production of IFN- $\gamma$ by the splenocytes in these groups compared with the Zn-deficient group. A report by Shi et al. ${ }^{(20)}$ indicated that splenic T-cells from $\mathrm{Zn}$-deficient mice that were infected by a parasite (Heligmosomoides polygyrus) produce less IL-4 and IL-5 (Th2 cyokines not examined in the present study) compared with control and pair-fed animals when exposed to the parasite antigen ex vivo, suggesting that Th2 cytokine production can also be lowered by $\mathrm{Zn}$ deficiency. Taken together, these studies suggest that there is not a preferential shift in cytokine production due to $\mathrm{Zn}$ deficiency; however, there is an overall decreased ability to respond to antigen in $\mathrm{Zn}$ deficiency and the shift in cytokine production may be reflecting whether the stimulus elicits a predominantly Th1 or Th2 response.

IL-6 is known as a glucocorticoid-increasing factor, which stimulates the hypothalamus-pituitary-adrenal axis to increase the release of corticotrophin-releasing hormone in the paraventricular nucleus of the hypothalamus, which stimulates secretion of pituitary adrenocorticotropic hormone which turns on the production of corticosterone in the adrenal gland ${ }^{(21)}$. IL-6 production by splenocytes was not affected by dietary treatment; therefore, the higher serum corticosterone concentration in the $\mathrm{Zn}$-deficient and pair-fed groups compared with the marginally $\mathrm{Zn}$-deficient and control groups cannot be explained by increased IL- 6 production by splenocytes in these groups. A possible explanation for the lack of a difference in IL- 6 cytokine production among dietary treatment groups could be that $48 \mathrm{~h}$ was not optimal to catch the peak production of each of the cytokines examined. In the present study, serum IL-6 was not measured; however, a previous study by our laboratory showed that plasma adrenocorticotropic hormone and serum $\mathrm{TNF} \alpha$ concentrations (another glucocorticoid-increasing factor) were not altered in $\mathrm{Zn}$-deficient or pair-fed groups compared with control ${ }^{(22)}$; thus the signalling mechanisms for elevated serum corticosterone require further elucidation.

In summary, the present study indicates that severe $\mathrm{Zn}$ deficiency was associated with a lower proportion of both new cytotoxic T-cells and new helper T-cells in spleen as well as lower production of Th1 cytokines (IL-2, IFN- $\gamma$ ) but not Th2 cytokines (IL-6, IL-10) by stimulated splenocytes. Cytokine production (IL-2 and IL-6) by stimulated thymocytes was reduced in $\mathrm{Zn}$-deficient, pair-fed and marginally $\mathrm{Zn}$-deficient rats despite no alteration in thymocyte numbers relative to thymus weight. In vivo corticosterone concentrations were not associated with altered cytokine production ex vivo. The results also indicate that a mild reduction in $\mathrm{Zn}$ status (marginally $\mathrm{Zn}$-deficient group) can alter cell function and that cell dysfunction can be detected before any phenotypic alterations occur. The present study demonstrates the value of including a marginally $\mathrm{Zn}$-deficient group, a model that may be more clinically relevant than the Zn-deficient group that is frequently used in studies of this type.

\section{Acknowledgements}

There are no conflicts of interest. Funding to C. G. T. was provided by the Natural Sciences and Engineering Research Council of Canada. H. J. H. B. performed all the laboratory work, analysis of the data derived from the various experimental procedures, statistical analysis, wrote the manuscript and received feedback from the co-authors. E. S. R. operated the flow cytometer and acquired all of the flow cytometry data. C. G. T. provided intellectual guidance at all stages. We thank the staff of the Animal Holding Facility, Laura Burr, Jody Van Deynze and Lisa Rigaux for their assistance with animal care. We also thank Dr Keith Fowke, Department 
of Medical Microbiology at the University of Manitoba, his technician Steve Wayne, Dr Magdy Dawood from Cadham Provincial Public Health Laboratories and his technician Gerry Smart for allowing us access to the Luminex system.

\section{References}

1. Guilbert JJ (2003) The world health report 2002 - reducing risks, promoting healthy life. Educ Health (Abingdon) 16, 230.

2. Hambidge M (2000) Human zinc deficiency. J Nutr 130, Suppl. 5S, 1344S-1349S.

3. Prasad AS (2000) Effects of zinc deficiency on Th1 and Th2 cytokine shifts. J Infect Dis 182, Suppl. 1, S62-S68.

4. Mosmann TR \& Sad S (1996) The expanding universe of T-cell subsets: Th1, Th2 and more. Immunol Today 17, 138-146.

5. Tanaka Y, Shiozawa S, Morimoto I \& Fujita T (1990) Role of zinc in interleukin 2 (IL-2)-mediated T-cell activation. Scand $J$ Immunol 31, 547-552.

6. Sprietsma JE (1997) Zinc-controlled Th1/Th2 switch significantly determines development of diseases. Med Hypotheses 49, 1-14.

7. Richter M, Bonneau R, Girard M-A, Beaulieu C \& Larivée P (2003) Zinc status modulates bronchopulmonary eosinophil infiltration in a murine model of allergic inflammation. Chest 123, Suppl. 3, 446S.

8. Yarilin AA \& Belyakov IM (2004) Cytokines in the thymus: production and biological effects. Curr Med Chem 11, 447-464.

9. van der Meer MJ, Sweep CG, Rijnkels CE, Pesman GJ, Tilders FJ, Kloppenborg PW \& Hermus AR (1996) Acute stimulation of the hypothalamic-pituitary-adrenal axis by IL- $1 \beta$, TNF $\alpha$ and IL-6: a dose response study. J Endocrinol Invest 19, 175-182.

10. Iwakabe K, Shimada M, Ohta A, Yahata T, Ohmi Y, Habu S \& Nishimura T (1998) The restraint stress drives a shift in Th1/ Th2 balance toward Th2-dominant immunity in mice. Immunol Lett 62, 39-43.

11. Lepage LM, Giesbrecht JA \& Taylor CG (1999) Expression of $\mathrm{T}$ lymphocyte p56(lck), a zinc-finger signal transduction protein, is elevated by dietary zinc deficiency and diet restriction in mice. $J$ Nutr 129, 620-627.
12. Clegg MS, Keen CL, Lonnerdal B \& Hurley LS (1981) Influence of ashing technique on the analysis of trace elements in animal tissues. Biol Trace Elem Res 3, 107-115.

13. Varas A, Vicente A, Romo T \& Zapata AG (1997) Role of IL-2 in rat fetal thymocyte development. Int Immunol 9, $1589-1599$.

14. Kopf M, Baumann H, Freer G, Freudenberg M, Lamers M, Kishimoto $\mathrm{T}$, Zinkernagel R, Bluethmann $\mathrm{H}$ \& Kohler $\mathrm{G}$ (1994) Impaired immune and acute-phase responses in interleukin-6-deficient mice. Nature 368, 339-342.

15. Mackall CL, Hakim FT \& Gress RE (1997) T-cell regeneration: all repertoires are not created equal. Immunol Today 18, 245-251.

16. Hosea HJ, Rector ES \& Taylor CG (2003) Zinc-deficient rats have fewer recent thymic emigrant (CD90+) T lymphocytes in spleen and blood. J Nutr 133, 4239-4242.

17. Dardenne M, Savino W, Wade S, Kaiserlian D, Lemonnier D \& Bach JF (1984) In vivo and in vitro studies of thymulin in marginally zinc-deficient mice. Eur $J$ Immunol 14, 454-458.

18. Beck FW, Prasad AS, Kaplan J, Fitzgerald JT \& Brewer GJ (1997) Changes in cytokine production and T cell subpopulations in experimentally induced zinc-deficient humans. Am J Physiol 272, E1002-E1007.

19. Hassan J \& Reen DJ (2001) Human recent thymic emigrants identification, expansion, and survival characteristics. J Immunol 167, 1970-1976.

20. Shi HN, Scott ME, Stevenson MM \& Koski KG (1998) Energy restriction and zinc deficiency impair the functions of murine $\mathrm{T}$ cells and antigen-presenting cells during gastrointestinal nematode infection. J Nutr 128, 20-27.

21. Wang J \& Dunn AJ (1999) The role of interleukin-6 in the activation of the hypothalamo-pituitary-adrenocortical axis and brain indolemamines by endotoxin and interleukin-1 $\beta$. Brain Res 815, 337-348.

22. Hosea HJ, Rector ES \& Taylor CG (2004) Dietary repletion can replenish reduced $\mathrm{T}$ cell subset numbers and lymphoid organ weight in zinc-deficient and energy-restricted rats. $\mathrm{Br} J$ Nutr 91, 741-747. 